\title{
Variation in Leaf Anatomy of Pecan Cultivars from Three Ecogeographic Locations
}

\author{
Madhulika Sagaram and Leonardo Lombardini ${ }^{1}$ \\ Texas A\&M University, Department of Horticultural Sciences, TAMU 2133, College Station, TX 77843 \\ L.J. Grauke \\ Pecan Genetics and Breeding Program, Agricultural Research Service, U.S. Department \\ of Agriculture, 10200 FM50, Somerville, TX 77879
}

\begin{abstract}
AdDitional Index words. Carya illinoinensis, ecogeographical traits, stomatal density, stomatal index, trichome density
Abstract. An assessment of leaf anatomic traits of pecan [Carya illinoinensis (Wangenh.) C. Koch] cultivars (Pawnee, Mohawk, and Starking Hardy Giant) collected from three locations (Tifton, GA; Chetopa, KS; and Stillwater, OK) was conducted to provide an understanding of patterns of ecogeographical variation within the natural range. Acetate casts of representative leaves were prepared for microscopic characterization of epidermal traits (stomatal density, stomatal index, and epidermal cell density). There were differences among the three pecan cultivars at the same location, but there were no differences in stomatal density within the same cultivar grown at three distinct locations. The stomatal density of 'Pawnee' leaves $\left(404 \mathrm{stomata} / \mathrm{mm}^{2}\right)$ was intermediate between that of 'Mohawk' (363 stomata/ $\mathbf{m m}^{2}$ ) and 'Starking Hardy Giant' (463 stomata/mm²). 'Pawnee' had the greatest epidermal cell density (2511 cells/ $\mathbf{~ m m}^{2}$ ) whereas 'Starking Hardy Giant' showed the least (1414 cells $\left./ \mathbf{m m}^{2}\right)$. Within a location, stomatal index differed significantly among cultivars, with 'Starking Hardy Giant' having a greater stomatal index than the other two cultivars. There were no differences in stomatal index across locations. 'Mohawk' had the greatest trichome density (18.92 trichomes $/ \mathrm{mm}^{2}$ ) whereas 'Starking Hardy Giant' had the lowest $\left(9.6\right.$ trichomes $\left./ \mathrm{mm}^{2}\right)$. The study suggests that differences in stomatal density and epidermal cell density in pecans are cultivar specific rather than being determined by environmental factors. The stability of certain leaf anatomic characteristics, such as stomatal and epidermal cell density, for pecan cultivars grown at different locations confirms that these traits can be used for screening provenances with desirable leaf anatomic characteristics for breeding and cultivar development.
\end{abstract}

Pecan has been known for centuries for its edible nuts and is the most valuable nut tree native to North America (Hall, 2000). It is a species distributed over an area of geographical and climatic variation extending from northern Illinois and southeastern Iowa to the Gulf Coast of the United States (Thompson and Grauke, 1991). This riparian species grows abundantly along the Mississippi River, the rivers of central and eastern Oklahoma, and the Edwards Plateau in Texas. Because the species is widely distributed across varied environmental conditions, it has developed anatomic and morphological differences within the provenances (Grauke et al., 2003; Nemati and Roberts, 1968). Today, pecan is commercially produced outside its native range in Georgia, California, Arizona, New Mexico, and western Texas, where environmental conditions can differ from those of its native range.

Received for publication 11 Dec. 2006. Accepted for publication 29 Mar. 2007. This project was funded in part by a Specific Cooperative Agreement (SCA 58-6202-6-095) between USDA-ARS Southern Plains Area and the Texas Agricultural Expt. Sta.

Mention of a trademark, proprietary product, or vendor does not constitute a guarantee or warranty of the product by the authors, the Texas A\&M University, the Texas Agricultural Expt. Sta., or sponsors of the research, and does not imply its approval to the exclusion of other products or vendors that also may be suitable.

We thank Dr. Brian Shaw, Department of Plant Pathology and Microbiology, Texas A\&M University, for allowing the use of the microscope equipment; Dr. Patrick Conner, Department of Horticulture, University of Georgia, Dr. William Reid, Pecan Experiment Station, Kansas State University, and Dr. Michael W. Smith, Department of Horticulture and Landscape Architecture, Oklahoma State University, for providing the leaf samples.

${ }^{1}$ Corresponding author. E-mail: 1-lombardini@tamu.edu.
Traits affecting the use and assimilation of resources such as carbon, water, and nutrients directly influence physiological processes and plant growth and development (Ackerly et al., 2000). According to Jones (1998), features of leaf surface anatomy are a complex of traits defined by stomatal characteristics (density, frequency, and position) and epidermal characteristics (density, shape, and size of epidermal cells).

Although flower (Amling and Amling, 1983; Wood, 2000; Wood et al., 1997), fruit (Grauke et al., 2001; Rehman et al., 1999; Rohla et al., 2005; Thompson, 2005) and leaf characteristics, such as leaflet area, specific leaf area, nutrient content (Grauke et al., 2003), and cuticular content (Chortyk et al., 1995) of pecan have received considerable attention, little information is available regarding additional leaf anatomic characteristics such as stomatal and epidermal cell density and number and types of trichomes (Grauke, 1982; Nemati and Roberts, 1968). Trichomes are hairlike structural elements of the epidermis of plants that play a role in plant defense (Levin, 1973), water use efficiency (Johnson, 1975), and temperature regulation (Ehleringer and Björkman, 1978). In juvenile pecan trees, three different types of trichomes-namely, awnlike hairs, concave peltate, and bladderlike or vesicular trichomeswere observed and described (Grauke et al., 1987). Because of their importance in regulation of water loss and water use efficiency, leaf anatomic characteristics could be useful traits for cultivar development, particularly in selection for drought tolerance. This study was undertaken to characterize the leaf anatomic features of three pecan cultivars at various geographical locations and to investigate the influence of cultivar and environment on stomatal density and epidermal cell density. 


\section{Materials and Methods}

Plant material. Leaves from three pecan cultivars (Pawnee, Mohawk, and Starking Hardy Giant) were obtained from three major pecan growing regions - namely, Tifton, GA

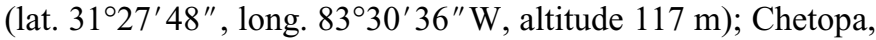
KS (lat. $37^{\circ} 02^{\prime} 15^{\prime \prime} \mathrm{N}$, long. $95^{\circ} 5^{\prime} 31^{\prime \prime} \mathrm{W}$, altitude $229 \mathrm{~m}$ ); and Stillwater, OK (lat. $36^{\circ} 07^{\prime} 18^{\prime \prime} \mathrm{N}$, long. $97^{\circ} 04^{\prime} 7^{\prime \prime} \mathrm{W}$, altitude $300 \mathrm{~m}$; Fig. 1). Two fully expanded leaves were selected from exterior north-facing canopy positions at 8 to $10 \mathrm{~m}$ from the ground (top third) of five 25- to 35-year-old trees. Leaf samples were collected between 25 Sept. and 2 Oct. 2005 and were shipped overnight to the Texas A\&M University laboratory in College Station, TX, and acetate leaf casts were made immediately upon receipt of the material.

SAMPLE PREPARATion. Pecan leaves are hypostomatic with anomocytic stomata (Grauke, 1982). Consequently, only the leaf abaxial sides were investigated. To determine the density of stomata, epidermal cells, and trichomes, the abaxial side of the distal pair of leaflets was coated with clear nail enamel (Fisher, 1985). After the enamel was allowed to dry for 10 to 15 min, the cast was stripped using clear tape and was placed on microscope slides.

Microscopy. A microscope (model BX51; Olympus America Inc., Melville, NY) was used to count epidermal cells and stomata from each cast at a magnification of $200 \times$. The microscope was attached to a digital camera (model DP70; Olympus America) interfaced with a personal computer. Differential interference contrast (DIC) images from 10 different interveinal areas of each cast were collected using DP70BSW software (version 01.01; Olympus America). Precautions were taken to avoid taking images in the same location by keeping a numbering system for the veins. In pecan, stomata are raised on the abaxial surface of the leaf in comparison with the epidermal cells. Hence, two DIC images were taken on each

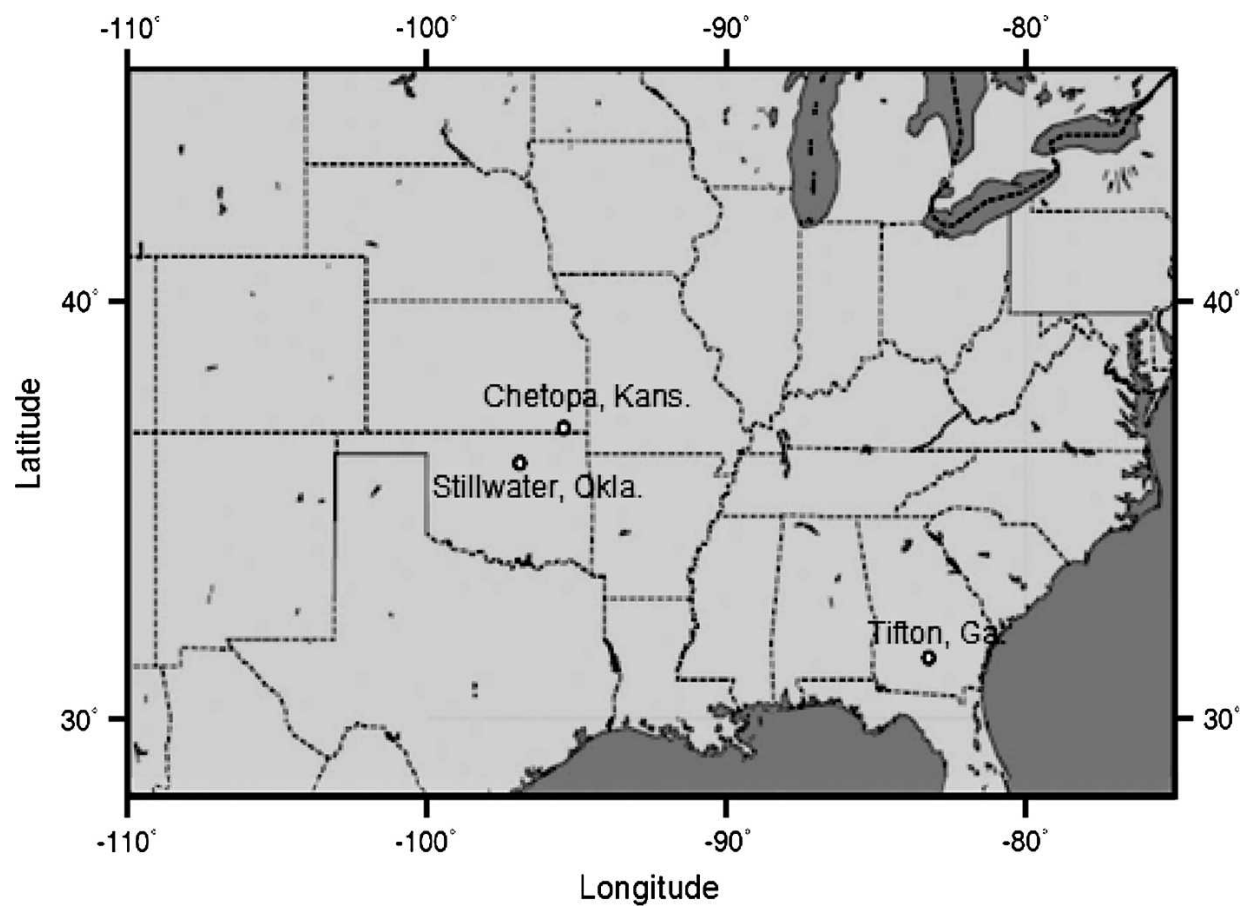

Fig. 1. Collection sites used in the study to investigate leaf anatomic features of pecan cultivars Pawnee, Mohawk, and Starking Hardy Giant. chosen area on the cast, one with the focus adjusted to highlight the epidermal cells and eliminate the stomata into the background (Fig. 2, top) and a second one with the focus on stomata and trichomes (Fig. 2, bottom). The number of stomata and epidermal cells from each image was recorded and analyzed for stomatal density (SD; measured in stomata per square millimeter) and epidermal cell density (ED; measured in epidermal cells per square millimeter). Stomatal index (SI) was calculated as $[\mathrm{SD} /(\mathrm{SD}+\mathrm{ED})] \times 100$. Total trichome density $(\mathrm{TD}$; measured in trichomes per square millimeter) and the type of trichomes - namely, concave peltate and bladder (Fig. 3) were recorded for each cultivar at different locations.

STATISTICAL DESIGN AND ANALYSIS. The experiment was set up as a $3 \times 3$ factorial (cultivar $\times$ location) design. Variability and cultivar differentiation was estimated via analysis of variance using SAS (SAS Institute, Cary, NC).

\section{Results}

Stomatal density differed among the three pecan cultivars investigated (Table 1), but there were no effects of location on SD within a cultivar. 'Starking Hardy Giant' (463 stomata/ $\mathrm{mm}^{2}$ ) had $15 \%$ more stomata per leaf area than 'Pawnee' (403 stomata $/ \mathrm{mm}^{2}$ ), and 28\% more stomata than 'Mohawk' (363 stomata $/ \mathrm{mm}^{2}$; Table 1). Similar to SD, ED was different among cultivars grown at the same location (Table 1), but it showed no differences across locations. 'Starking Hardy Giant' exhibited the least ED of all three cultivars (1413 cells $\left./ \mathrm{mm}^{2}\right)$, 'Pawnee' had the greatest $\left(2510\right.$ cells $\left./ \mathrm{mm}^{2}\right)$, whereas 'Mohawk' showed an intermediate value $\left(2210\right.$ cells $/ \mathrm{mm}^{2}$; Table 1$)$. There were large differences in SI between 'Starking Hardy Giant' $(24.65 \%)$ and the other two cultivars at each location (14.06\% and $13.86 \%$ in 'Mohawk' and 'Pawnee' respectively; Table 1). However, there were no differences across locations within cultivars.

The density of bladder-type trichomes in 'Pawnee' and 'Starking Hardy Giant' was similar at all locations (Table 2). In 'Mohawk', the density was greater in leaves from Stillwater and Chetopa than in those from Tifton. At Stillwater and Chetopa, 'Mohawk' and 'Starking Hardy Giant' displayed the greatest and the least density of bladder-type trichomes respectively. At Tifton, the density of bladder-type trichomes in 'Pawnee' and 'Mohawk' was greater than in 'Starking Hardy Giant'. The density of concave peltate-type trichomes did not change in 'Mohawk' across locations (Table 2). In 'Pawnee', the density of concave peltatetype trichomes at Tifton and Stillwater differed. In 'Starking Hardy Giant' the density at Stillwater and Chetopa was greater than at Tifton. At Tifton and Stillwater, there were differences in TD among all three cultivars, with 'Pawnee' showing an intermediate number of trichomes (Table 2). At Tifton, TD was greatest 

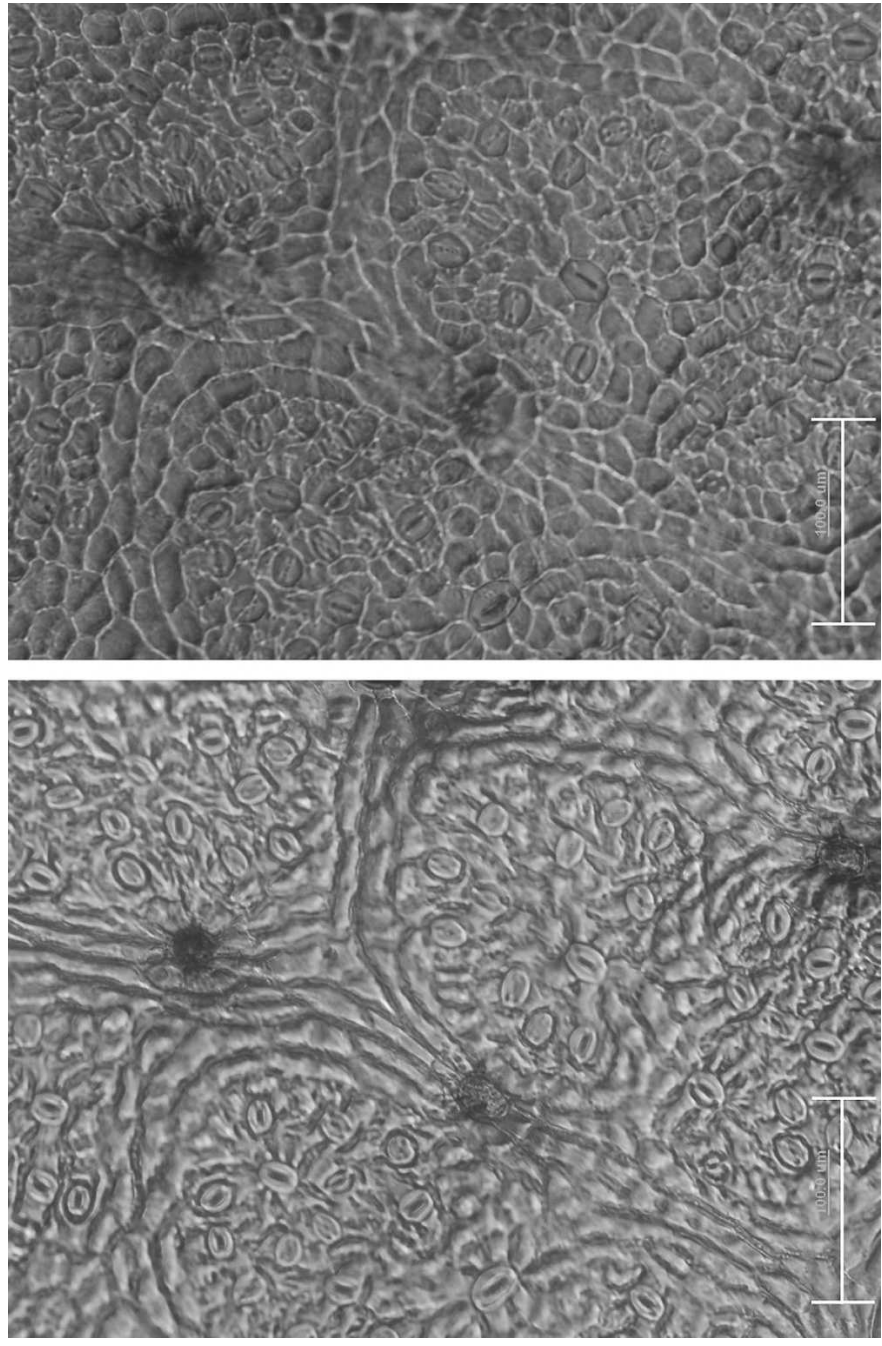

Fig. 2. Images of the abaxial surface of 'Mohawk' pecan leaves showing epidermal cells (top) and stomata (bottom) visible on two different focal planes of the same microscopic view. Bar $=100 \mu \mathrm{m}$.

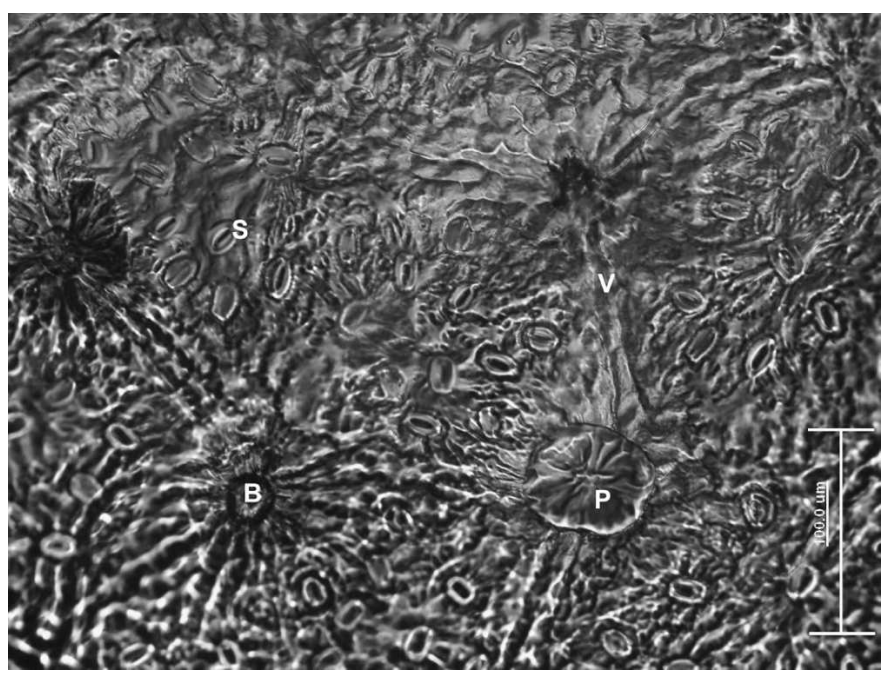

Fig. 3. Types of trichomes observed on the abaxial surface of 'Mohawk' pecan leaves. Bar $=100 \mu \mathrm{m}$. B, bladder trichome; $\mathrm{P}$, concave peltate trichome; $\mathrm{S}$, stomata; $\mathrm{V}$, leaf vein. in 'Mohawk' followed by 'Pawnee' and 'Starking Hardy Giant'. At Stillwater, TD in 'Starking Hardy Giant' was less than that in the other two cultivars (Table 2). At Chetopa, there were no differences between 'Pawnee' and 'Starking Hardy Giant'. 'Starking Hardy Giant' was the only cultivar that displayed differences in TD among the locations, with lesser number of trichomes recorded at Tifton than at Stillwater and Chetopa (Table 2).

\section{Discussion}

The current results suggest that SD, ED, and SI are stable within a pecan cultivar despite ecogeographical differences in the growing sites. Differences between cultivars were maintained across locations, with 'Pawnee' showing the greatest ED of the three cultivars, and intermediate SD between 'Mohawk' and 'Starking Hardy Giant'.

Trichome density is an anatomic characteristic that can be influenced by environmental factors such as light intensity (Upadhyaya and Furness, 1998) and resource availability (Wilkens et al., 1996). Species might diverge in response to the selection pressure in a specific region, thus resulting in differences in trichome type and density within and between taxa in ecogeographical correlations (Levin, 1973). The types of trichomes and patterns of TD observed in this study varied at the three locations and were different between cultivars.

Glandular trichomes not only represent a physical impediment for aphid movement, but they also secrete sticky exudates (Levin, 1973). Density of trichomes could be related to gradients in abiotic components of the environment, such as solar radiation, and altitude. Glandularity of trichomes is less likely influenced by the environment, because it has negligible effects on the biophysical properties of the leaf surface (Levin, 1973). The glandularity may be a result of long-term predator pressure and differences in predation from one region to the other (Levin, 1973). Analogous patterns for TD at Chetopa and Stillwater may be the result of similar geographical and environmental conditions or similar predator pressure (Fig. 1).

Stomatal densities have been related to tolerance to abiotic stress conditions, such as drought (Jarvis and Davies, 1998; Van Rensburg et al., 1999) and temperature extremes (Kleinhenz et al., 1995; Nayeem, 1989). However, stomatal response to elevated $\mathrm{CO}_{2}$ had contrasting results, varying from a decrease in SD (Lin et al., 2001; Woodward and Kelly, 1995) to a lack of stomatal acclimation within a single generation in wheat (Triticum aestivum L.) and sour oranges (Citrus aurantium L.) (Estiarte et al., 1994). In a survey conducted to study the influence of $\mathrm{CO}_{2}$ concentration on SD of several species grown in controlled environment, Woodward and Kelly (1995) found that changes in SD were generally greater in samples from amphistomatous species than those from hypostomatous species, such as pecan. This indicates that certain species may not show plasticity to environmental changes in a single generation for some ecogeographical traits.

Pecan SD ranged from 363 to 463 stomata $/ \mathrm{mm}^{2}$ depending on the cultivar investigated. The values found here were similar to those reported previously for six other pecan cultivars (Giles, Gratex, Greenriver, Major, Peruque, and Western Schley; 288-462 stomata $/ \mathrm{mm}^{2}$ ) (Nemati and Roberts, 1968) and for walnut (Juglans regia L.; (250-450 stomata/ $\mathrm{mm}^{2}$ ) (Bongi and Paris, 2006), but greater than those reported for other temperate climate trees, such as olive (Olea europaea L.; 
Table 1. Stomatal density, epidermal cell density, and stomatal index recorded on leaves of pecan cultivars collected from three different locations.

\begin{tabular}{llccc}
\hline Location & \multicolumn{1}{c}{ Cultivar } & $\begin{array}{c}\text { Stomatal density } \\
\left(\text { stomata } / \mathrm{mm}^{2}\right)\end{array}$ & $\begin{array}{c}\text { Epidermal cell } \\
\text { density }\left(\text { epidermal cells } / \mathrm{mm}^{2}\right)\end{array}$ & $\begin{array}{c}\text { Stomatal } \\
\text { index }(\%)\end{array}$ \\
\hline Tifton, GA & Pawnee & $404 \mathrm{~b}^{\mathrm{z}}$ & $2,518 \mathrm{a}$ & $13.85 \mathrm{~b}$ \\
& Mohawk & $363 \mathrm{c}$ & $2,201 \mathrm{~b}$ & $14.05 \mathrm{~b}$ \\
\multirow{5}{*}{ Stillwater, OK } & Starking Hardy Giant & $462 \mathrm{a}$ & $1,417 \mathrm{c}$ & $24.60 \mathrm{a}$ \\
& Pawnee & $406 \mathrm{~b}$ & $2,501 \mathrm{a}$ & $13.97 \mathrm{~b}$ \\
& Mohawk & $362 \mathrm{c}$ & $2,218 \mathrm{~b}$ & $14.05 \mathrm{~b}$ \\
Chetopa, KS & Starking Hardy Giant & $463 \mathrm{a}$ & $1,409 \mathrm{c}$ & $24.72 \mathrm{a}$ \\
& Pawnee & $401 \mathrm{~b}$ & $2,513 \mathrm{a}$ & $13.78 \mathrm{~b}$ \\
& Mohawk & $363 \mathrm{c}$ & $2,211 \mathrm{~b}$ & $14.10 \mathrm{~b}$ \\
& Starking Hardy Giant & $463 \mathrm{a}$ & $1,415 \mathrm{c}$ & $24.65 \mathrm{a}$ \\
\hline
\end{tabular}

${ }^{\mathrm{z}}$ Means within same column for a location indicated by different letters are significantly different at $P \leq 0.05$ by Fisher's LSD. Means within the same column for a cultivar are not significantly different at $P \leq 0.05$ by Fisher's LSD, and thus mean separation is not indicated.

Data are the average of 10 microscopy images from each of 10 leaves investigated per cultivar.

270-350 stomata $/ \mathrm{mm}^{2}$ ) and stone pine (Pinus pinea L.; 280 345 stomata $/ \mathrm{mm}^{2}$ ) (Woodward and Kelly, 1995).

This study illustrates distinct differences in epidermal features of the leaf in different cultivars. 'Pawnee' originated in 1963 from a controlled cross of 'Mohawk' and 'Starking Hardy Giant' (Thompson and Hunter, 1985). It was released in 1984 and it is now the most widely planted pecan cultivar (Thompson and Grauke, 2000). 'Starking Hardy Giant' is a northern cultivar propagated from a native tree grown in Brunswick, MO, in 1950 (Grauke and Thompson, 1997). 'Mohawk' is a pedigreed cultivar originated in 1946 by the controlled cross of two southern cultivars ('Success' $x$ 'Mahan') by the U.S. Department of Agriculture (Grauke and Thompson, 1997).

The results of the current investigation showed that the values for SD and ED did not change for the same cultivar at different ecogeographical locations. Consequently, the SI remained constant for a cultivar grown in different locations.

Table 2. Type and density of trichomes recorded on leaves of pecan cultivars collected from three different locations. Data are average of 10 microscopy images from each of 10 leaves investigated per cultivar.

\begin{tabular}{clccc}
\hline & & \multicolumn{3}{c}{ Trichome density (trichomes $/ \mathrm{mm}^{2}$ ) } \\
\cline { 3 - 5 } Trichome type & \multicolumn{1}{c}{ Cultivar } & \multicolumn{1}{c}{ Tifton, } & Stillwater, & Chetopa, \\
OA & KS \\
\hline Bladder & Pawnee & $7.60 \mathrm{a}^{\mathrm{z}} \mathrm{A}^{\mathrm{y}}$ & $9.34 \mathrm{bA}$ & $8.83 \mathrm{bA}$ \\
& Mohawk & $6.58 \mathrm{aB}$ & $13.76 \mathrm{aA}$ & $14.26 \mathrm{aA}$ \\
& Starking Hardy & & & \\
& Giant & $2.89 \mathrm{bA}$ & $3.11 \mathrm{cA}$ & $3.04 \mathrm{cA}$ \\
Concave & & & & \\
peltate & Pawnee & $2.82 \mathrm{cB}$ & $4.20 \mathrm{bA}$ & $3.62 \mathrm{bAB}$ \\
& Mohawk & $6.52 \mathrm{aA}$ & $8.25 \mathrm{aA}$ & $7.39 \mathrm{aA}$ \\
& Starking Hardy & & & \\
Total & Giant & $4.42 \mathrm{bB}$ & $7.02 \mathrm{aA}$ & $8.33 \mathrm{aA}$ \\
& Pawnee & $10.42 \mathrm{bA}$ & $13.54 \mathrm{bA}$ & $12.45 \mathrm{bA}$ \\
& Mohawk & $13.10 \mathrm{aA}$ & $22.01 \mathrm{aA}$ & $21.65 \mathrm{aA}$ \\
& Starking Hardy & & & \\
& Giant & $7.31 \mathrm{cB}$ & $10.13 \mathrm{cA}$ & $11.37 \mathrm{bA}$ \\
\hline
\end{tabular}

${ }^{\mathrm{z}}$ Means within the same column indicated by different letters (lowercase) are significantly different at $P \leq 0.05$ by Fisher's LSD. ${ }^{\mathrm{y}}$ Means within the same row indicated by different letters (uppercase) are significantly different at $P \leq 0.05$ by Fisher's LSD.
This indicates that SD may be linked to the long-term climatic conditions of the location where the species (or cultivar) developed, and it may not be a very plastic trait within an individual generation of trees/cultivars. It is of great interest to understand the extent of plasticity of the ecogeographical traits to determine the stability and the possible use of the traits in breeding. In Arabidopsis thaliana (L.) Heynh., SD has been linked to mechanisms of instantaneous water use efficiency (transpiration efficiency), indicating the importance of the trait for plant survival in drought conditions (Masle et al., 2005).

In conclusion, the stability of certain leaf anatomic characteristics, such as $\mathrm{SD}$ and $\mathrm{ED}$, for pecan cultivars grown at different locations confirms that these traits can be used for screening ecotypes and provenances for breeding and cultivar development.

\section{Literature Cited}

Ackerly, D.D., S.A. Dudley, S.E. Sultan, J. Schmitt, J.S. Coleman, C.R. Linder, D.R. Sandquist, M.A. Geber, A.S. Evans, T.E. Dawson, and M.J. Lachowicz. 2000. The evolution of plant ecophysiological traits: Recent advances and future directions. Bioscience 50:979-995.

Amling, H.J. and K.A. Amling. 1983. Physiological differentiation of pistillate flowers of pecan and cold requirements for their initiation. J. Amer. Soc. Hort. Sci. 108:195-198.

Bongi, G. and P. Paris. 2006. Leaflet heterogeneity in Juglans regia: An un-adverted bias in assimilation models. Acta Hort. 705:251255.

Chortyk, O.T., I.E. Yates, and C.C. Reilly. 1995. Changes in cuticular compounds of developing pecan leaves. J. Amer. Soc. Hort. Sci. 120:329-335.

Ehleringer, J.R. and O. Björkman. 1978. Pubescence and leaf spectral characteristics in a desert shrub, Encelia farinosa. Oecologia 36:151-162.

Estiarte, M., J. Penuelas, B.A. Kimball, S.B. Idso, R.L. LaMorte, P.J. Pinter, Jr., G.W. Wall, and R.L. Garcia. 1994. Elevated $\mathrm{CO}_{2}$ effects on stomatal density of wheat and sour orange trees. J. Expt. Bot. 45:1665-1668.

Fisher, D.G. 1985. Morphology and anatomy of the leaf of Coleus blumei (Lamiaceae). Amer. J. Bot. 72:392-406.

Grauke, L.J. 1982. The influence of zinc carriers on the foliar absorption of zinc by pecan and corn. Texas A\&M Univ., College Station, TX, PhD Diss.

Grauke, L.J., J.B. Storey, and E.R. Emino. 1987. Influence of leaf age on the upper and lower leaf surface features of juvenile and adult pecan leaves. J. Amer. Soc. Hort. Sci. 112:835-841. 
Grauke, L.J. and T.E. Thompson. 1997. The Brooks and Olmo register of fruit and nut varieties, 3rd ed. ASHS Press, Alexandria, VA.

Grauke, L.J., T.E. Thompson, J.B. Storey, and L. Sistrunk. 2001. Variation in pecan kernel composition in relation to genotype, crop load, and leaf nutrition levels. HortScience 36:498 (abstr.).

Grauke, L.J., B.W. Wood, T.E. Thompson, and J.B. Storey. 2003. Population of origin affects leaf structure and nutrient concentration of pecan seedlings. HortScience 38:663 (abstr.).

Hall, G.D. 2000. Pecan food potential in prehistoric North America. Econ. Bot. 54:103-112.

Jarvis, A.J. and W.J. Davies. 1998. The coupled response of stomatal conductance to photosynthesis and transpiration. J. Expt. Bot. 49:399-406.

Johnson, H.B. 1975. Plant pubescence: An ecological perspective. Bot. Rev. 41:233-258.

Jones, H.G. 1998. Stomatal control of photosynthesis and transpiration. J. Expt. Bot. 49:387-398.

Kleinhenz, M.D., J.B. Bamberg, and J.P. Palta. 1995. Use of stomatal index as a marker to screen backcross populations of two wild potato species segregating for freezing tolerance. Amer. Potato J. $72: 243-250$.

Levin, D.A. 1973. The role of trichomes in plant defense. Qrtly. Rev. Biol. 48:3-15.

Lin, J., M.E. Jach, and R. Ceulemans. 2001. Stomatal density and needle anatomy of scots pine (Pinus sylvestris) are affected by elevated $\mathrm{CO}_{2}$. New Phytol. 150:665-674.

Masle, J., S.R. Gilmore, and G.D. Farquhar. 2005. The ERECTA gene regulates plant transpiration efficiency in arabidopsis. Nature 436:866-870.

Nayeem, K.A. 1989. Genetic and environmental variation in stomatal frequency and distribution in wheat Triticum spp. Cereal Res. Commun. 17:51-57.
Nemati, A. and C.R. Roberts. 1968. Some structural differences in the leaves of six pecan cultivars and the possible significance to production. Ann. Rpt. Northern Nut Growers Assn. 59:96-99.

Rehman, N., I. Hussain, Z. un Nisa, and A.A. Awan. 1999. Germination study on five different varieties of pecan nut. Pakistan J. Biol. Sci. 2:917-918.

Rohla, C.T., M.W. Smith, and N.O. Maness. 2005. Effects of cluster size and shoot type on characteristics of pecan nuts. HortScience 40:1300-1303.

Thompson, T.E. 2005. Pecan fruit shuck thickness is related to nut quality. HortScience 40:1664-1666.

Thompson, T.E. and L.J. Grauke. 1991. Pecans and other hickories (Carya). Acta Hort. 290:839-904.

Thompson, T.E. and L.J. Grauke. 2000. 'Pawnee' pecan. J. Amer. Pomol. Soc. 54:110-113.

Thompson, T.E. and R.E. Hunter. 1985. 'Pawnee' Pecan. HortScience 20:776.

Upadhyaya, M.K. and N.H. Furness. 1998. Primocane morphology and leaf surface characteristics of greenhouse-grown red raspberry cultivars. HortScience 33:330-332.

Van Rensburg, L., J. Peacock, and G.H.J. Krueger. 1999. Boundary layer, stomatal geometry and spacing, in relation to drought tolerance in four Nicotiana tabacum L. cultivars. South Afr. J. Plant Soil 16:44-49.

Wilkens, R.T., G.O. Shea, S. Halbreich, and N.E. Stamp. 1996. Resource availability and the trichome defenses of tomato plants. Oecologia 106:181-191.

Wood, B.W. 2000. Pollination characteristics of pecan trees and orchards. HortTechnology 10:120-126.

Wood, B.W., M.W. Smith, R.E. Worley, P.C. Anderson, T.T. Thompson, and L.J. Grauke. 1997. Reproductive and vegetative characteristics of pecan cultivars. HortScience 32:1028-1033.

Woodward, F.I. and C.K. Kelly. 1995. The influence of $\mathrm{CO}_{2}$ concentration on stomatal density. New Phytol. 131:311-327. 